\title{
ChARACTERISTICS AND SWOT ANALYSIS OF Serbian Vehicle and Automotive Parts MANUFACTURERS
}

\author{
KOKIC, M. \& VREKIC, S.
}

Abstract: Several thousand manufacturers, which have their branches in many countries, participate in the manufacture of parts for the world automotive industry. The best ones among them have achieved the status of reliable OEM suppliers, because they develop independently their parts and components and offer them to vehicle manufacturers throughout the world. The biggest 100 suppliers of components have an impressive share in the total revenue, 5 billion dollars on the average per year, per manufacturer. For the local manufacturers of automotive parts in Serbia, to find their place on the world market and maintain their position on the local market, it is necessary that they firstly introduce strict world quality standards, revitalize the existing equipment and technology, train their staff and provide conditions for an independent development and testing of their products. A real test for local manufacturers of automotive parts is to be able to master over the production of parts and components following the world standards for the requirements of the materialization of projects related to the assembly of new vehicle models, which is planned for the coming period in our country. It is estimated that without finding strategic partners for local final manufacturers of vehicles, there are not many opportunities for an independent presentation of component manufacturers on the world market.

Key words: market, components, SWOT analysis
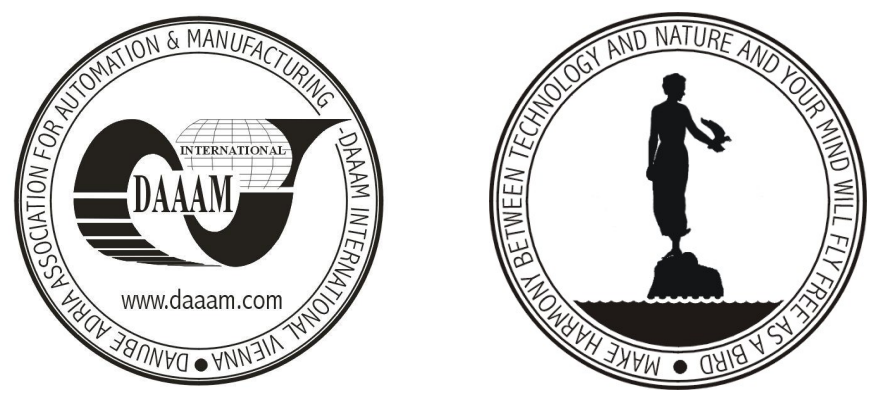

Authors' data: $\mathrm{PhD}$ Eng. Kokic, M[iljko]; M Sc Eng. Vrekic, S[nezana], Zastava Vehicles Group, 34000 Kragujevac, Serbia, m.kokic@zastava.net, snezanav@ia.kg.ac.yu

This Publication has to be referred as: Kokic, M. \& Vrekic, S. (2007). Characteristics and Swot Analysis of Serbian Vehicle and Automotive Parts Manufacturers, Chapter 53 in DAAAM International Scientific Book 2007, B. Katalinic (Ed.), Published by DAAAM International, ISBN 3-901509-60-7, ISSN 1726-9687, Vienna, Austria DOI: $10.2507 /$ daaam.scibook.2007.53 